\title{
EMPLOYMENT PRACTICES AND OPPORTUNITIES FOR WOMEN: WHY VOLUNTARY AFFIRMATIVE ACTION IS INADEQUATE
}

\author{
K. EDWARD RENNER \\ and \\ LESLIE GILLIS \\ Dalhousie University
}

\begin{abstract}
In a survey of employment practices and the employment structure in Halifax, extensive segregation of work was found. Only $17 \%$ of 978 categories of work offered by 195 employers contained both male and female employees. The official policy of the Government of Canada is for voluntary rather than mandatory affirmative action. This policy was reaffirmed in 1984 for another five-year period. It was concluded that voluntary programs are unlikely to be successful because employers who are the source of the segregated work must either correct a situation which is not recognized as discrimination, or alter the segregation of work they prefer.
\end{abstract}

In Canada, the Human Rights Act of 1975 prohibits discrimination in employment practices or policies on the grounds of sex, age, marital status, race, national or ethnic origin, color, religion, physical handicap, or a criminal conviction for which a pardon has been granted. It is also a discriminatory practice for an employer to establish or maintain a difference in wages between male and female workers employed in the same establishment who are performing work of equal value.

The social policy developed to correct the effects of past or present employment discrimination is affirmative action. Canada has provided specific legislation that it shall not be a discriminatory practice for an employer to implement a special program to reduce a demonstrated disadvantage suffered by a particular race, sex, or national origin group (Employment and Immigration Canada, 1980). However, Canada has recently re-affirmed its option for voluntary, rather than legislated, affirmative action for the next five years, based on the report of an all male special committee of the House of Commons (Daudlin, 1984). This action was taken just prior to a Royal Commission Report being tabled in the House which recommended a mandatory program (Abella, 1984).

The concept and definition of discrimination in employment opportunity is 
crucial to the analytical task of deciding when affirmative action may be necessary, and when necessary, whether it should be voluntary or mandatory. Specifically, there are three different assumptions which may be made, each requiring different types of information to determine whether discrimination is present, and when it is, what types of corrective procedures are appropriate.

The simplest approach is access discrimination in which specific employers are assumed to have exercised intentional preferences to award either men or women particular positions. From this point of view, discrimination is an isolated event due to the intentions of identifiable individuals or organizations, and the need is to change the attitudes or practices of those particular individuals. In contrast, differential discrimination minimizes the importance of individual intentions. Discrimination is assumed to exist when the criterion used for decisions or judgements results in differential or unequal practices. And finally, systemic discrimination focuses simply on the consequences of an employment system. Discrimination is assumed to exist whenever an employment practice has an exclusionary impact on a particular group, without the need to establish either evil intentions or differential practices. For example, the simple word-of-mouth announcement of a new position in an all male workforce could effectively limit equal employment opportunity without either evil intentions or differential standards by the employer.

In the present study we analyzed a data file of occupational positions used by a job counselling program to compile descriptive information about the employment structure in Halifax. This information was used first to illustrate the implications of applying each of the three concepts of discrimination, and second to evaluate whether voluntary or mandatory affirmative action is most appropriate.

\section{METHOD}

As part of a Community Psychology class project to provide job counselling to ex-offenders, a data file of employers and job opportunities was compiled over the two-year period of 1980 and 1981. A card file of all known employers in Halifax was created using the yellow pages, a directory of local business, and information provided by local organizations such as the Better Business Bureau and Chamber of Commerce. From this list, major employers for a wide variety of unskilled and semi-skilled jobs were selected to be interviewed. The goal was not a random selection, but rather to construct as comprehensive an information file as possible of the most probable places to look for work, for example, hotels, retail stores, domestic and commercial cleaners. Students selected the specific places they would visit on the basis of knowledge and convenience; those with retail experience visited stores, and companies were selected on personally traveled routes to make call-backs easier. Once selected, persistence was the rule. If one student failed to gain access, another would often try at another time. No precise record was kept of the refusal rate, although those doing the interviews estimated it to be less than five percent. Students were first trained in interviewing skills and then practiced using the questionnaire through role playing before beginning data collection. They worked in pairs to provide a double check on the information obtained. Subsequent class efforts have been made to keep the file current for job counselling purposes and to add some additional employers to the card catalogue each year. 
Interview data was available for 195 companies in Halifax. Each employer had been asked 43 questions regarding wages, number of employees, and hiring standards and procedures, for each type of position within his or her company. Some employers had only one type of position to offer (such as labour work for commercial cleaning) while other employers, such as hospitals, had several major categories (e.g., cleaning, food service, and clerical) each with a different hiring criterion. In all, a total of 978 separate categories of work were contained in the data file, accounting for 10,333 full-time and 4,665 part-time jobs; a total of 14,998 actual employment positions.

\section{RESULTS}

\section{What Employers Say and What They Do}

For most $(75 \%)$ of the job categories, employers said they did not have a preference for either males or females (i.e., for that category of work either sex was appropriate and acceptable to the employer). These employer-defined "equal opportunity" job categories accounted for a total of 11,280 jobs which were potentially open to both sexes. Of these employment categories, only $24 \%$ did in fact include both men and women (for a total of 4,907 "equal opportunity" jobs). Although saying they would hire either sex, $30 \%$ hired only women (accounting for 2,384 jobs) and $46 \%$ hired only men (accounting for 3,749 jobs). The breakdown by sex of the actual number of employees in each job category was available for all but 240 of the 11,280 jobs for which employers stated they had no gender preference.

\section{Segregated Work}

For the $25 \%$ of job categories (accounting for 3,718 jobs) in which the employers expressed a preference for either men $(16 \%)$ or women $(9 \%)$, they exclusively hired their preference in over $91 \%$ of the categories. In these cases an individual employer believed the work to be appropriate either for only men (e.g., driving a truck) or only women (e.g, a receptionist). The net effect was that of all the employment categories, $51 \%$ had no females and $32 \%$ had no males. Only $17 \%$ of the total number of separate job classifications did in fact hire both men and women (See Figure 1). A nearly identical pattern existed for both full-time and part-time work.

\section{Employment Practices}

Pay level was recorded into five categories allowing us to assess the wages paid for men's and women's work. Those job categories filled exclusively by men paid more than those filled exclusively by women with $X^{2}(4, N=576)=48.05$, $p<.0001$. For example, $80 \%$ of the men but only $56 \%$ of the women received five dollars or more per hour at the time of the initial survey. Of those employers who hired only women, $85 \%$ said they used physical appearance as a criterion for hiring, but of those who hired exclusively males, physical appearance was used $61 \%$ of the time with $\mathrm{X}^{2}(2, \mathrm{~N}=708)=44.52, p<.0001$. 
FIGURE 1

Percentage of Job Categories

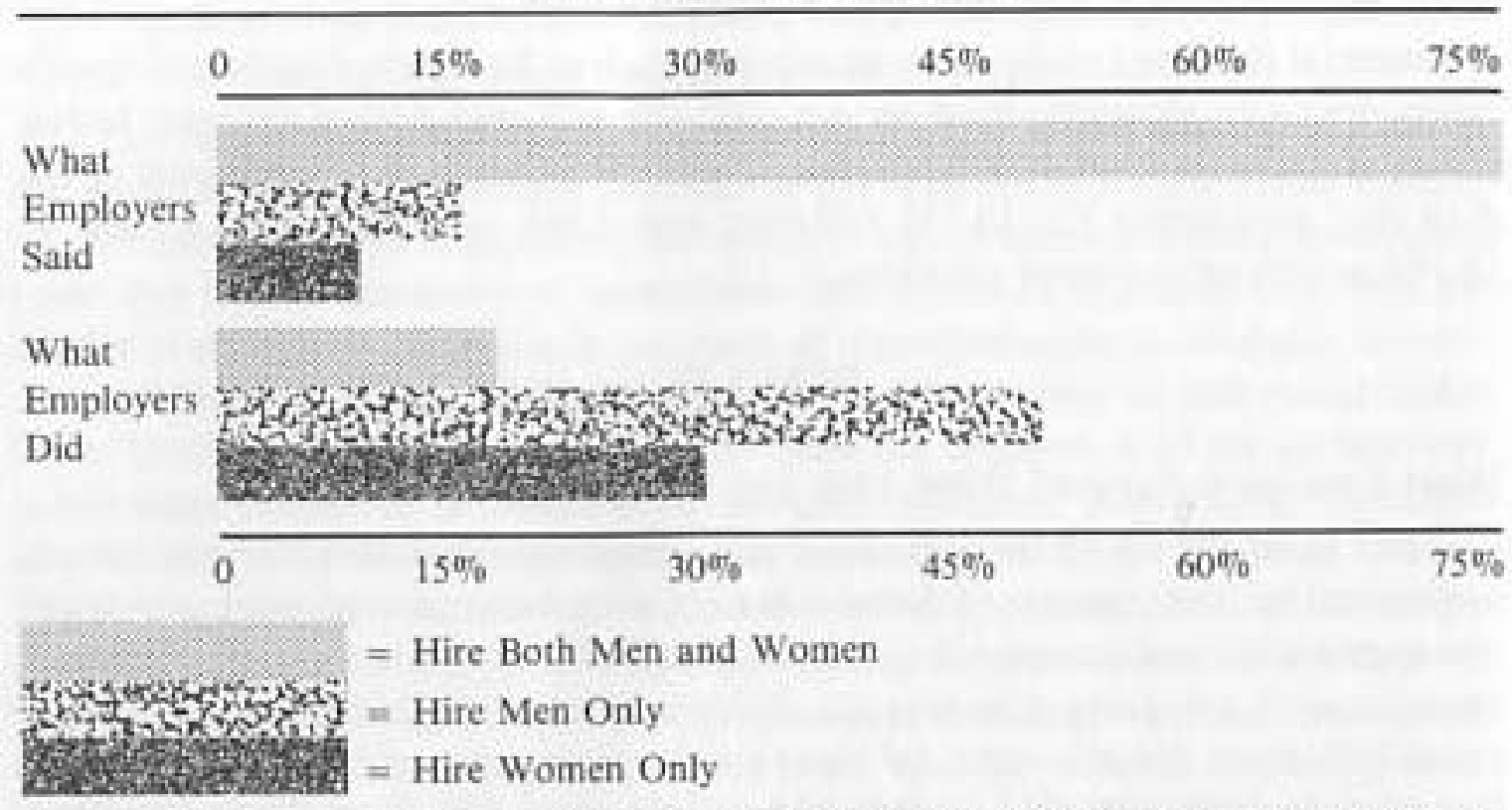

Percentage of employment categories for which employers said they would hire both men and women, men only, or women only, and the percentage of employment categories in which employers did hire both men and women, men only, or women only.

\section{DISCUSSION}

\section{Why Systemic Discrimination Is the Appropriate Concept}

Our data show only that there is segregation of work. While this is a necessary consequence of discrimination, it is not sufficient evidence for establishing that discrimination exists, unless the concept of discrimination is based upon the assumption of its systemic nature. The other two concepts of access and differential treatment simply shift responsibility from the employer to the employee.

From the viewpoint of access, discrimination is an isolated event due to the intentions of an identifiable individual or organization. Therefore, before our findings of segregated work could be considered as evidence of discrimination, other explanations must be rejected. For example, women may not have applied for the higher paying jobs held by men. Such possibilities shift blameworthiness away from the intentions or actions of the employer to the behaviour or characteristics of the applicants who then become the objects of data collection and analysis. This may become an example of what Ryan (1971) termed "blaming the victim."

Although information such as application rates and levels of qualification are theoretically possible to collect, no uniform minimum standards for these types of records exist in Canada. Such information, even if available, is difficult to evaluate because applicants may be reactive to the actions of the employer who by policy or practice may selectively discourage particular applicants. A similar situation exists with the concept of differential discrimination. Employers are not required to calculate average salary by both sex and experience, and even if they 
did, there is no provision for outside access unless an individual employee has filed a human rights complaint. Responsibility is again placed on the individual to establish that discrimination has taken place, not on the employer to document as a matter of regularly kept records that differential treatment does not happen.

In contrast, systemic discrimination exists whenever any employment practice has a differential or an exclusionary impact on a particular group, unless the employer can show the policy is necessary for legitimate occupational needs. As an illustration, police departments have sometimes imposed height, weight, or strength requirements which effectively exclude women; and, it is then a matter for debate whether these criteria are required for the job. At most, $25 \%$ of our job categories were of this type, where the employer for one reason or another stated and exercised a preference based on sex. Such openly acknowledged cases can be dealt with on their own merit as a general issue of employment opportunity, rather than as one of personal suitability, only through a systemic concept of discrimination. Few, if any, of our cases were as extreme as the police example.

A systemic approach avoids the issue of assigning blame. It is the only definition for which our evidence of segregated work would be sufficient grounds for the immediate conclusion in over $50 \%$ of the categories of work of an exclusionary impact. The findings would therefore legally justify the appropriateness of initiating affirmative action procedures within the employment practices used by the employer to ensure equality of opportunity. With any approach other than a systemic one, employers can continue employment practices which produce the segregation of work, such as filling positions through screening walk-ins and other informal approaches without documentation, advertising, or public listings with employment centres.

\section{Why Voluntary Affirmative Action Is Inadequate}

Information and records. Voluntary affirmative action is a vicious circle. There is no requirement in Canada for the regular collection of information nor for the maintenance of records necessary to support or refute the inference of employment discrimination. Without such information there is no basis for any demonstrable need for an affirmative action program, and therefore no such program can be legally implemented. An employer who wishes to practice simple access discrimination can do so with minimal effort; and those who discriminate without intention or awareness have no reason to question their own fairness. In either case no routinely available information exists that can be used to detect or correct the practice.

One chain of stores in our survey was listed by the Nova Scotia Human Rights Commission as having signed with them an affirmative action agreement. Yet when we visited the individual personnel officers in the separate stores where actual hiring takes place, they were, with one exception, unaware of the agreement. None could produce a copy of the affirmative action procedures to be followed. Only the central management of the chain and the Commission were informed about the agreement, and neither knew how it was being implemented. Given the differences we have found between what is said and what is done, there is little reason for confidence that the two are the same. The selective knowledge or ignorance about such matters is a voluntary choice of the employer. Mandatory programs, such as recommended by the Royal Commission (Abella, 1984), make provisions for essential records and information as a minimum condition. 
Exceptionalism. The Canadian Human Rights Commission operates on the basis of individual cases and therefore largely at the level of access and differential discrimination on the basis of individual complaints. For example, the Correctional Services of Canada denied employment to the top-ranking candidate for a counselor position because he was perceived as a security risk, having had a criminal conviction for which a pardon had been granted. This discrimination by Correctional Services was not withstanding the fact that they have special positions within their own department to encourage private sector employers to hire ex-offenders. The Canadian Human Rights Commission intervened in this case and Correctional Services Canada "voluntarily" offered the position to the candidate when this particular individual was "no longer judged as a security risk" (Canadian Human Rights Commission, 1981). No court action was taken. No policy was changed. No new documentation is now required of Correctional Services to demonstrate continued future compliance.

After the completion of our study we were able to gain some short-lived media attention which, at best, made a small contribution to the general level of local awareness. However, we were unable to initiate any significant local changes. The obvious strategy was to have employers with clearly identifiable patterns of segregated work approached about their employment practices by an agency with the legal authority to authorize and implement an affirmative action program. As an example, Canada Employment Centres are an excellent data source on employers, the types of positions listed, and their actual hiring practices. They were not interested in extending our approach to their own data, which was regarded as "confidential," for use in this direct way. Rather, they preferred their own procedure of trying to persuade employers to establish voluntary programs, in accordance with the official policy of the Government of Canada. More to the point, however, was the very real concern that an aggressive program based on actual data, but without the legal authority and obligation for either having compiled the information or initiating class actions, would simply result in employers no longer listing positions with Canada Employment Centres, or in the case of our data source, no longer cooperating with the counselling program. This is a form of intimidation employers can use to resist unwanted external interference.

A case-by-case investigation of complaints and unmonitored voluntary agreements will not be effective. In Ryan's (1971) terms, such approaches are based on an "exceptionalistic" strategy that a few isolated cases need to be corrected which result from a few well-intended but misinformed employers. At best, a few individuals will be helped by these current strategies. However, the problems of employment opportunity and employment structures will persist until involuntary procedures are established which are "universalistic," and which will support or refute the universal inference of non-discrimination apart from individual cases, and when necessary, will allow legal intervention into the systemic nature of both employment opportunities and employment structures.

\section{CONCLUSIONS}

The issue of employment opportunity and the employment structure goes to the heart of the political and social search for justice. The status quo, however, 
appears to be the predictable future, unless Canadians are prepared to enter into the political and philosophical issues of equality of employment opportunity in a way that will be involuntary and intrusive into the day-to-day practices of those who control both access and conditions of employment.

Behind the issue of equality of employment opportunity is greater economic independence for women, and with such independence, increased freedom from the social and psychological consequences of oppression that women share with other disadvantaged groups. Ultimately, women's independence and greater range of self-expression is also a challenge to the fundamental nature of the relationship between men and women (Freeman, 1984). The challenge will not, of course, be easy for either men or women. But, sex roles are next in the progression of human rights which must now include equality in employment opportunity and employment structures.

As it now stands those who are the source of segregated work are the ones who must be counted upon to take voluntary action to either correct what they honestly do not recognize as employment discrimination, or to correct the segregation they intentionally prefer. Voluntary affirmative action is not adequate.

\section{RESUME}

Un sondage effectué à Halifax a révélé que la ségrégation était largement répandue dans les pratiques et les structures de l'emploi. Des 978 catégories d'emplois offerts par 195 employeurs, seulement $17 \%$ s'adressaient aussi bien aux femmes qu'aux hommes. La politique officielle du gouvernement canadien prèconise des mesures incitatives plutôt que des mesures coercitives pour augmenter la proportion des emplois accessibles aux femmes. Cette politique a été réaffirmée en 1984 pour une autre période de cinq ans. On arrive à la conclusion que les programmes volontaires ne semblent pas donner les résultats attendus parce que les employeurs qui sont à la source de cette sègrégation doivent soit corriger une situation qu'eux-mëmes ne considèrent pas discriminatoire soit modifier une situation de ségrégation qu'ils préfèrent maintenir.

\section{REFERENCES}

Abella, R. (1984). Equality in employment: A Royal Commission report, Ottawa: Supply and Services Canada.

Canadian Human Rights Commission. (1981. August 10). Correctional services agrees to hire pardoned ex-convict. Ottawa: Canadian Human Rights Commission.

Daudlin, R. (1984). Equality now: Report of the Special Committee on Visible Minorities in Canadian Society. Ottawa: House of Commons (available through Supply and Services Canada).

Freeman, J. (1984). The woman's liberation movement: Its origins, structures, activities, and ideas. In I. Freeman (Ed.), Women: A feminist perspective (3rd ed.). Palo Alto, CA: Mayfield Publishing.

Employment and Immigration Canada. (1980). Affirmative action: What's it all about? Ottawa: Supply and Services Canada.

Ryan, W. (1971), Blaming the victim. New York: Random House. 